\title{
Changes in qualities of potato and potato-soy snacks during high temperature short time (HTST) air puffing
}

\begin{abstract}
Two different potato based ready-to-eat (RTE) snacks were prepared using high temperature short time (HTST) air puffing followed by oven toasting and evaluated for its nutritional changes that took place during high temperature short time air puffing and oven toasting process. The nutritional composition of initial samples before puffing and oven toasting and final products were measured in terms of moisture content $(\%$ $\mathrm{db})$, protein $(\%)$, fat $(\%)$, ash $(\%)$, crude fiber $(\%)$, carbohydrates $(\%$, by difference), ascorbic acid content $(\mathrm{mg} / 100 \mathrm{~g})$, nitrogen solubility index (\%), protein digestibility $(\%)$, trypsin inhibitor activity (\%), calorific value ( $\mathrm{Kcal} / 100 \mathrm{~g})$ and protein energy ratio. Significant increase in protein $(56.67 \%)$, ash (70.49\%), crude fiber $(27.2 \%)$ and protein energy ratio $(63.20 \%)$ were recorded in RTE potato-soy snack as compared to RTE potato snack due to addition of soy flour $(10.26 \%)$ in the product.
\end{abstract}

Keywords: ready-to-eat, potato, soy flour, nutrition, high temperature short time air puffing, oven toasting
Volume 8 Issue 6 - 2018

\author{
Nath A, Chattopadhyay PK \\ Post Harvest Technology, Division of Horticulture, ICAR \\ Research Complex for NEH Region, India
}

\begin{abstract}
Correspondence: Nath A, Sr. Scientist, Post Harvest Technology, Division of Agricultural Engineering, ICAR Research Complex for NEH Region, Umiam, Meghalaya, India, Tel +91364-2570678, Fax +9l-364-2570678,

Email amitmath2005@gmail.com
\end{abstract}

Received: December 21, 2017 | Published: November 28, 2018

\section{Introduction}

Consumers in the recent world are becoming increasingly aware of the relationship between diet and health. Thus, the demand for a balanced diet and nutrient composition of food products that address specific health benefits is growing steadily. Processing and cooking conditions cause changes in availability of different food nutrients. During production of ready-to-eat (RTE) foods, several changes in nutrient composition take place in processing steps and become very important for process formulation. The dehydration process, which is generally more widely applied to potatoes than to fruit and vegetables, can be very destructive to L-AA with losses of $75 \%$ being reported Mishkin et al. ${ }^{1}$ The effect of different combination of puffing temperature, puffing time, moisture content and air velocity on ascorbic acid content of ready-to eat dehydrated puffed potato cubes was reported by Mukherjee et al. ${ }^{2}$ It reported that the maximum ascorbic acid loss $(14.48 \mathrm{mg} / 100 \mathrm{~g}$ dry matter) and minimum $(3.12 \mathrm{mg} / 100 \mathrm{~g}$ dry matter) was observed at the process conditions of $175^{\circ} \mathrm{C}, 125 \mathrm{~s}, 45 \%(\mathrm{wb})$ and $3.6 \mathrm{~m} / \mathrm{s}$ and $150^{\circ} \mathrm{C}, 50 \mathrm{~s}, 35 \%(\mathrm{wb})$ and $3.0 \mathrm{~m} / \mathrm{s}$ respectively. Haase et al. ${ }^{3}$ observed degradation of ascorbic acid during processing of French fries and potato chips. During processing total losses of ascorbic acid were about $52 \%$ for French fries and about $26 \%$ for potato chips respectively. Losses of vitamin $\mathrm{C}$ during processing depend on the degree of heating, ${ }^{4}$ leaching into the cooking medium, surface area exposed to oxygen and any other factors that facilitate oxidation. ${ }^{5}$

The effect of temperature in decreasing the activity of soy product trypsin inhibitors is well known and described in the literature. ${ }^{6}$ Thermal inactivation of trypsin inhibitors of soybean preparations added to meat was reported by Kozlowska et al. ${ }^{7}$ and they found heat treatments at 70 and $100^{\circ} \mathrm{C}$ for $5 \mathrm{~min}$ reduced the trypsin inhibitor activity in the product by 40 and $70 \%$ respectively, in comparison with unheated samples. By extending the heating time upto $15 \mathrm{~min}$, further reduction of activity, by about 20 and $4 \%$ was caused at 70 and $100^{\circ} \mathrm{C}$ respectively while, Dublish et al. ${ }^{6}$ studied on nutritional quality of extruded rice, ragi and defatted soy flour blends and they observed extrusion cooking resulted in the inactivation of trypsin inhibitor activity and at 65 and $95 \pm 2^{\circ} \mathrm{C}$ the inactivation was $42.6-71.4$ and $72.3-100 \%$, respectively.

Nitrogen Solubility Index (NSI) is frequently used as indicators of protein functionality and potential end use. ${ }^{8}$ NSI is considered to be a good index of the potential use of a protein, providing information that is useful in snack foods processing and optimization. Several functional properties are directly related to this type of heat treatment. ${ }^{9}$ Heat treatment to the food materials leads to alterations in specific structure of the proteins. In many instances, increase in digestibility of the protein occurs, perhaps by opening of the complex structure which serves as the site for digestive enzyme. ${ }^{10}$ Bhole ${ }^{11}$ studied on the development of cereal-pulses based convenience food and it reported $14.72 \%$ and $5.54 \%$ increase in nitrogen solubility index and in vitro protein digestibility index respectively in the developed product. Quality evaluation of three canteen snacks: nutritative, fat and bacteriological was reported by Goyle et al. ${ }^{12}$ They observed that the energy contents of the snacks were in between 249 and 475 $\mathrm{kcal} / 100 \mathrm{~g}$. There is no literature available on nutritional changes that took place during high temperature short time (HTST) air puffed potato and potato-soy snack production. Therefore, the present study was undertaken to evaluate the nutritional changes that took place during the production of RTE potato and potato-soy snacks.

\section{Materials and methods}

\section{Preparation of potato flour}

Potato flour was prepared from freshly harvested potatoes (Kufri chandramukhi) as per the method described by Nath et al..$^{13}$ The potato flour obtained were packed in air-tight containers and kept in dry and cold place for future use. 


\section{Preparation of soy flour}

Soy beans (Glycine max Cv. JS 335) were procured from local market and washed thoroughly with clean water. Immediately after washing and sorting, raw soybean seeds were blanched for $15 \mathrm{~min}$ in hot water $\left(100^{\circ} \mathrm{C}\right)$. Blanched soybeans were dehulled by manual rubbing. Splits obtained were steamed for $10 \mathrm{~min}$. and then dried at $60^{\circ} \mathrm{C}$ for 5-6hours in hot air cabinet drier up to a final moisture content of $8-10 \% .{ }^{14}$ The dried splits were ground in a domestic grinder (Sumeet Brand) for 15-20min and passed through the sieve (British Sieve Standards) to yield flour of 50 mesh size. The soy flour thus obtained was packed in air-tight containers for future use.

\section{Sample preparation}

RTE potato and potato-soy snack were prepared from potato flour dough with about $37 \%(\mathrm{wb})$ moisture content along with $2 \% \mathrm{NaCl}$ and $10 \%$ soy flour added in total weight of potato flour respectively. Dolly pasta machine (LaMonferrina Make) was used to prepare a rectangular shape $(15-20 \mathrm{~mm}$ length, $10 \mathrm{~mm}$ width and $1.5 \mathrm{~mm}$ thickness) dimension chips from the dough. These chips were air puffed in a high temperature short time (HTST) fluidized bed air puffer specially designed and fabricated for the purpose Nath et al. ${ }^{15}$ These snacks were subjected to oven toasting ${ }^{13}$ for obtaining final RTE potato and potato-soy snack. The nutritional composition of initial samples before puffing and oven toasting and final products were measured in terms of moisture content, protein, fat, ash, crude fiber, carbohydrates (by difference), ascorbic acid content, nitrogen solubility index, protein digestibility, trypsin inhibitor activity, calorific value and protein energy ratio.

\section{Moisture content}

The moisture content of the samples at every stage of the process was determined by hot air oven method as described by Ranganna. ${ }^{16}$

\section{Protein content}

Protein Content was determined by AOAC ${ }^{17}$ method No. 2.049 Protein content was estimated as per equations given below:

nitrogen $\%=\frac{[\{\text { Sample titre }- \text { Blank titre }\} \times \text { Normality of } H C l \times 4 \times \text { Volume made up of the digest } \times 100}{\text { Aliquot of the digest taken } \times \text { Weight of the sample taken } \times 1000}$

$$
\text { Protein }=\text { Nitrogen } \% \times 6.25
$$

\section{Crude fiber content}

It was determined according to $\mathrm{AOAC}^{17}$ method No. 7.054. Crude fiber content was estimated as per Eq 3 and 4 shown below:

$\%$ crude fibre in ground sample $=C=\frac{\text { (lose in weight on ignition }- \text { loss in weight of asbestos bank }) \times 100}{\text { weight of the sample }}$

$\%$ crude fibre on derived moisture basis $=C \times=\frac{(100-\% \text { moisture disived }}{(100-\% \text { moisture in } \text { ground sample }}$

\section{Ash, fat and carbohydrate content}

Ash content was determined according to AOAC. ${ }^{17}$ However, fat soluble material in snack food was extracted from an oven- dried sample using a Soxhlet extraction apparatus with solvent hexane. Fat content was estimated as per Eq 5 shown below:
$\%$ Fat content $=\mathrm{Wt}$ of fat-soluble material $* 100 / \mathrm{Wt}$ of sample

The carbohydrate content was estimated by subtracting the values of moisture, protein, ash, crude fat and crude fiber from 100 .

\section{Ascorbic acid content}

The ascorbic acid content of the samples was determined by visual titration method using 2, 6-dichlorophenol-indophenol (Ranganna, 1995). ${ }^{16}$ The ascorbic acid content of the sample was calculated by the formula:

$$
\text { Ascorbic acid content }(\mathrm{mg} / 100 \mathrm{~g})=\frac{\text { Titre } \times \text { Dye factor } \times \text { Volume made up } \times 100}{\text { Aliquot of extract } \times \text { Volume of sample }}
$$

\section{Protein digestibility index}

In vitro protein digestibility was estimated by enzymatic method of Akeson et al. ${ }^{18}$ Digestibility was calculated using Eq 7 as shown below:

$$
\text { Protein digestibility }(\%)=\frac{\mathrm{N}_{2} \text { in supernatant }-\mathrm{N}_{2} \text { in sample blank at zero hour }}{\mathrm{N}_{2} \text { in sample }-\mathrm{N}_{2} \text { in enzyme blank (in TCA) }}
$$

\section{Nitrogen solubility index}

It was determined according to BIS ${ }^{19}$ method No. 7837. The nitrogen solubility index of the sample was calculated by using Eq 8 and 9 as shown below:

$$
\text { Water soluble nitrogen, percent by mass }=\frac{\left(\mathrm{V}_{1}-V_{2}\right) \times N \times 0.014 \times 100}{\mathrm{M}}
$$

$$
\text { Nitrogen solubility index }(\mathrm{NSI})=\frac{\text { Water soluble nitrogen }}{\text { Total nitrogen }} \times 100
$$

where, $\mathrm{V}_{1}$ (volume in $\mathrm{ml}$ of alkali for back titration of blank); $\mathrm{V}_{2}$ (volume in $\mathrm{ml}$ of alkali for back titration of sample); $\mathrm{N}$ (normality of alkali) and $\mathrm{M}$ (mass of sample).

\section{Trypsin inhibitor activity}

Trypsin inhibitor activity was determined according to $\mathrm{BIS}^{19}$ method No. 7837.

\section{Calorific value}

Calorific values $(\mathrm{kcal} / 100 \mathrm{~g})$ of both the raw materials and final products were calculated by summing up the multiplication of percent protein, fat and carbohydrate present in these materials by 4.04, 9.0 and 4.04 respectively. ${ }^{20}$

\section{Protein energy ratio}

The energy contributed by the protein to that of the total energy obtained from $100 \mathrm{~g}$ of the developed product was calculated by using Eq 10 as shown below:

$$
\text { Protein energy ratio }=\frac{\text { Total protein }(\%)}{\text { Total energy }(\mathrm{kcal} / 100 \mathrm{~g})} \text {. }
$$




\section{Statistical analysis}

Paired samples T-test were conducted using the statistical software 'SPSS, V-10' to compare the mean values of RTE potato snack with RTE potato-soy snack. The null hypothesis was tested and level of significant difference was also recorded between the products.

\section{Results and discussion}

\section{Preparation of potato flour and soybean flour}

Potato slices were dried at a temperature of $60^{\circ} \mathrm{C}$ in a hot air cabinet drier for 4hours in a single layer and obtained flour of 100 mesh sizes with drying ratios of 5.68 and yield of $16.2 \%$ with moisture content of $9.45 \%(\mathrm{db})$. However, soybean flour of 50 mesh size was obtained from dried soybean (Glycine max CV. JS 335) splits by grinding in a domestic grinder with final moisture content of $10.1 \%(\mathrm{db})$ and flour yield was recorded as $83.6 \%$.

\section{Proximate and nutritional compositions of raw materials}

Potato flour, soy flour and defatted soy flour were analyzed for their proximate compositions and nutritional properties (Table 1). Potato flour was found to be rich in carbohydrate $(75.52 \%)$ and ascorbic acid $(41.76 \mathrm{mg} / 100 \mathrm{~g})$. It was observed that defatted soy flour was rich in protein $(48.34 \%)$, ash $(6.92 \%)$ and crude fiber $(4.07 \%)$ as compared to full fat soy flour with protein $(40.16 \%)$, ash $(6.34 \%)$ and crude fiber $(3.81 \%)$. Defatted soy flour was found 5.5 times higher in protein energy ratio as compared to potato flour. The proximate compositions of potato flour presented in Table 1 was found consistent with the results reported by Kulkarni et al. ${ }^{21-23} \mathrm{Jha}^{24}$ reported $13-25 \%$ oil, 30$50 \%$ protein and $14-24 \%$ carbohydrate in soybean seed and these results are in agreement with the present findings. On the contrary, Akubor et al. ${ }^{25}$ reported higher values of carbohydrates (33\%) and fat $(18 \%)$ in soybean, which might be due to differences in agro-climatic conditions and varietal differences. Other nutritional compositions viz. nitrogen solubility index, protein digestibility index, energy value and protein energy ratio and were recorded as $65.70 \%, 83.44 \%$, $342.05 \mathrm{kCal} / 100 \mathrm{~g}$ and $0.024 ; 60.25 \%, 79.15 \%, 387.20 \mathrm{kCal} / 100 \mathrm{~g}$ and $0.104 ; 62.25 \%, 81.37 \%, 365.90 \mathrm{kCal} / 100 \mathrm{~g}$ and 0.132 respectively for potato flour, full fat and defatted soy flour (Table 1). However, trypsin inhibitor activity of full fat soy flour and defatted soy flour were recorded as $38.5 \%$ and $35.7 \%$ respectively which were much below the maximum prescribed limit of 55 units (BIS: 7836-1975 and 7837-1975).

\section{Nutritional properties of RTE potato snack and RTE potato-soy snack during processing}

The proximate composition and nutritional properties of RTE potato snacks and RTE potato-soy snacks (initial and final products) were analyzed and presented in Table 2. During processing the maximum loss of fat, protein, carbohydrates, ascorbic acid content and protein energy ratio were found to be $31.11 \%, 2.19 \%, 0.44 \%$, $31.87 \%$ and $1.28 \%$ respectively for RTE potato snack and $27.69 \%$, $2.25 \%, 0.53 \%, 30.12 \%$ and $1.05 \%$ respectively for RTE potatosoy snack while, the maximum loss of trypsin inhibitor activity was observed to be $63.66 \%$ for RTE potato-soy snack. Haase et al. ${ }^{3}$ also observed degradation of ascorbic acid during processing of French fries and potato chips. During processing total losses of AA were about $52 \%$ for French fries and about $26 \%$ for potato chips respectively. Losses of vitamin $\mathrm{C}$ during processing depend on the degree of heating, leaching into the cooking medium, surface area exposed to oxygen and any other factors that facilitate oxidation. ${ }^{5}$ The effect of temperature (i.e. processing) in decreasing the activity of soy product trypsin inhibitors is well known and described in the literature. ${ }^{26,6}$ Thermal inactivation of trypsin inhibitors of soybean preparations added to meat was reported by Kozlowska et al. ${ }^{7}$ and they found heat treatments at 70 and $100^{\circ} \mathrm{C}$ for $5 \mathrm{~min}$ reduced the trypsin inhibitor activity in the product by 40 and $70 \%$ respectively, in comparison with unheated samples. By extending the heating time up to $15 \mathrm{~min}$, further reduction of activity, by about 20 and $4 \%$ was caused at 70 and $100^{\circ} \mathrm{C}$ respectively while, Dublish et al. ${ }^{6}$ studied on nutritional quality of extruded rice, ragi and defatted soy flour blends and they observed extrusion cooking resulted in the inactivation of trypsin inhibitor activity and at 65 and $95 \pm 2{ }^{\circ} \mathrm{C}$ the inactivation was 42.6-71.4 and 72.3-100\%, respectively. However, during processing the maximum increase of ash content, crude fiber, nitrogen solubility index and in vitro protein digestibility index were recorded to be $16.99 \%, 2.42 \%, 12.69 \%$ and $8.59 \%$ respectively for RTE potato snack and $11.15 \%, 5.39 \%, 11.52 \%$ and $8.84 \%$ respectively for RTE potatosoy snack. It is observed that due to processing Nitrogen Solubility Index (NSI) and Protein Digestibilty Index (PDI) values were also increased and this may due to the release of some protein fraction into the products during processing. NSI are frequently used as indicators of protein functionality and potential end use. ${ }^{8} \mathrm{NSI}$ is considered to be a good index of the potential use of a protein, providing information that is useful in snack foods processing and optimization. Several functional properties are directly related to this type of heat treatment. ${ }^{9}$ Heat treatment to the food materials leads to alterations in specific structure of the proteins. In many instances, increase in digestibility of the protein occurs, perhaps by opening of the complex structure which serves as the site for digestive enzyme. ${ }^{10}$ Bhole ${ }^{11}$ studied on the development of cereal-pulses based convenience food and he reported $14.72 \%$ and $5.54 \%$ increase in nitrogen solubility index and in vitro protein digestibility index respectively in the developed product. Quality evaluation of three canteen snacks: nutritive value, fat and bacteriological was reported by Goyle et al. ${ }^{12}$ They observed that the energy contents of the snacks were in between 249 and $475 \mathrm{kcal} / 100 \mathrm{~g}$. These results are in agreement with the present findings.

\section{Comparison of nutritional properties of RTE potato snack with RTE potato-soy snack}

The mean values of nutritional parameters for RTE potato snack and RTE potato-soy snack and their standard deviations are presented in Table 3. The null hypothesis was tested and there was highly significant difference recorded between the products. High significant difference ( $\mathrm{p} \leq 0.01)$ between RTE potato snack and RTE potato-soy snack were found except for moisture content in which it was nonsignificant (Table 3). Significant increase in protein $(56.67 \%)$, ash (70.49\%), crude fiber $(27.2 \%)$ and protein energy ratio $(63.20 \%)$ of RTE potato-soy snack as compared to RTE potato snack has been recorded due to addition of soy flour $(10.26 \%)$ in the product. Laul et al. ${ }^{27}$ studied on the preparation of extruded finger shaped snack foods supplemented with defatted soybean to corn, broken rice and sorghum and they reported that addition of soy flour increased protein content in the finished product to $12 \%$ level. Soy flour incorporation in potato based foods like extruded and traditional type can, not only give better colored product, but will make more protein available for nutrition due to lesser formation of mailared product. ${ }^{28}$ These findings are in accordance with the present findings. 
Table I Proximate and Nutritional compositions of raw materials (potato flour and soy flour)

\begin{tabular}{llll}
\hline Parameters & Potato flour & \multicolumn{2}{l}{ Soy flour } \\
\cline { 3 - 4 } & & full fat & defatted \\
\hline MC, \%, db. & 9.5 & 10.1 & 9.8 \\
Fat, \%, db. & 0.46 & 12.4 & 1.3 \\
Protein, \%, db. & 8.1 & 40.2 & 48.3 \\
Ash, \%, db & 3.8 & 6.3 & 6.9 \\
Crude fiber, \%, db & 1.6 & 3.8 & 4.1 \\
Carbohydrates, \%* & 75.5 & 28.2 & 39.4 \\
Ascorbic acid, mg/I00g, db & 41.8 & 0.00 & 0.00 \\
Nitrogen solubility index, \% & 65.7 & 60.3 & 62.0 \\
Protein digestibility index, \% & 83.4 & 79.2 & 81.4 \\
Trypsin inhibitor activity, \% & - & 38.5 & 35.7 \\
Energy, Kcal/l00g & 342.1 & 387.2 & 365.9 \\
Protein Energy Ratio & 0.02 & 0.10 & 0.13 \\
\hline
\end{tabular}

*By difference

$\mathrm{MC}$, moisture content

Table 2 Changes in nutritional properties of RTE potato and RTE potato-soy snacks during processing

\begin{tabular}{|c|c|c|c|c|c|c|c|c|}
\hline \multirow[t]{2}{*}{ Parameters } & \multicolumn{2}{|c|}{$\begin{array}{l}\text { RTE potato } \\
\text { snack }\end{array}$} & \multirow{2}{*}{ Loss, \% } & \multirow{2}{*}{ Gain, \% } & \multicolumn{2}{|c|}{$\begin{array}{l}\text { RTE potato-soy } \\
\text { snack }\end{array}$} & \multirow{2}{*}{ Loss, \% } & \multirow{2}{*}{ Gain, \% } \\
\hline & Initial & Final & & & Initial & Final & & \\
\hline$M C, \%$ & 35.6 & 3.3 & 90.7 & & 35.6 & 3.4 & 90.6 & \\
\hline Fat, \% & 0.45 & 0.31 & 31.1 & & 0.65 & 0.47 & 27.7 & \\
\hline Protein, \% & 8.2 & 8.0 & 2.2 & & 12.9 & 12.6 & 2.3 & \\
\hline Ash, \% & 3.7 & 4.3 & & 16.9 & 6.6 & 7.3 & & 11.2 \\
\hline Crude fiber, $\%$ & 1.7 & I.7 & & 2.4 & 2.0 & 2.2 & & 5.4 \\
\hline Carbohydrates, \%* & 77.5 & 77.2 & 0.44 & & 69.4 & 68.9 & 0.53 & \\
\hline Ascorbic acid, mg/l00g & 37.2 & 25.4 & 31.9 & & 32.7 & 22.8 & 30.1 & \\
\hline Nitrogen solubility index & 66.4 & 74.9 & & 12.7 & 62.3 & 69.5 & & 11.5 \\
\hline Protein digestibility index & 85.2 & 92.6 & & 8.6 & 82.5 & 89.7 & & 8.8 \\
\hline Trypsin inhibitor activity & - & - & & & 3.6 & 1.3 & 63.7 & \\
\hline Energy, Kcal/l00g & 350.4 & 347.00 & 0.96 & & 338.1 & 333.8 & 1.3 & \\
\hline Protein Energy Ratio & 0.02 & 0.02 & 1.3 & & 0.04 & 0.04 & I.I & \\
\hline
\end{tabular}

* By difference

MC, moisture content; RTE, ready-to-eat 
Table 3 Comparison of nutritional properties of RTE potato snack with RTE potato-soy snack

\begin{tabular}{|c|c|c|c|c|c|}
\hline \multirow{2}{*}{ Parameters } & \multicolumn{2}{|l|}{$\operatorname{Mean} \pm$ SD } & \multirow{2}{*}{$\begin{array}{l}\% \\
\text { Variation }\end{array}$} & \multirow{2}{*}{$\begin{array}{l}\text { Standard error of } \\
\text { Mean }\end{array}$} & \multirow{2}{*}{$\begin{array}{l}\text { Sig } \\
\text { (2-tailed) }\end{array}$} \\
\hline & RTE potato & RTE potato-soy & & & \\
\hline $\mathrm{MC}, \%$ & $3.3 \pm 0.047$ & $3.4 \pm 0.049$ & 0.90 & 0.03 & 0.441 \\
\hline Fat, $\%$ & $0.31 \pm 0.023$ & $0.47 \pm 0.016$ & 51.6 & 0.02 & 0.000 \\
\hline Protein, \% & $8.0 \pm 0.093$ & $12.6 \pm 0.053$ & 56.7 & 0.04 & 0.000 \\
\hline Ash, \% & $4.3 \pm 0.041$ & $7.3 \pm 0.098$ & 70.5 & 0.05 & 0.000 \\
\hline Crude fiber, $\%$ & $1.7 \pm 0.070$ & $2.2 \pm 0.040$ & 27.2 & 0.03 & 0.000 \\
\hline Carbohydrates, $\% *$ & $77.2 \pm 0.684$ & $68.9 \pm 0.336$ & -10.6 & 0.36 & 0.000 \\
\hline Ascorbic acid, mg/100g & $25.4 \pm 0.186$ & $22.8 \pm 0.186$ & -10.0 & 0.14 & 0.000 \\
\hline Nitrogen solubility index & $74.9 \pm 0.380$ & $69.5 \pm 0.509$ & -7.6 & 0.25 & 0.000 \\
\hline Protein digestibility index & $92.6 \pm 0.207$ & $89.7 \pm 0.449$ & -3.0 & 0.22 & 0.000 \\
\hline Trypsin inhibitor activity & 0 & $1.3 \pm 0.100$ & & 0.04 & 0.000 \\
\hline Energy, Kcal/100g & $347.0 \pm 15.313$ & $333.8 \pm 1.625$ & -3.8 & 6.6 & 0.114 \\
\hline Protein Energy Ratio & $0.02 \pm 0.000$ & $0.04 \pm 0.000$ & 63.2 & 0.00 & 0.000 \\
\hline
\end{tabular}

* By difference

$\mathrm{MC}$, moisture content; SD, standard deviation; RTE, ready-to-eat

\section{Conclusion}

Significant changes in nutritional composition between RTE potato and RTE potato-soy snacks were observed during high temperature short time air puffing and oven toasting process. Addition of soy flour $(10.26 \%)$ caused increase in protein $(56.67 \%)$, ash $(70.49 \%)$, crude fiber $(27.2 \%)$ and protein energy ratio $(63.20 \%)$. The maximum loss of trypsin inhibitor activity was observed to be $63.66 \%$ for RTE potato-soy snack.

\section{Acknowledgments}

This research was carried out and supported by the Indian Institute of Technology (IIT), Kharagpur, India

\section{Conflicts of interest}

The authors have no conflicting financial or other interests.

\section{References}

1. Mishkin M, Saguy I, Karel M. A dynamic test for kinetic models of chemical changes during processing: Ascorbic acid degradation in dehydrated potatoes. Journal of Food Science. 1984;49:1276-1274.

2. Mukherjee S, Chattopadhyay PK. Whirling bed blanching of potato cubes and its effects on product quality. Journal of Food Engineering. 2007;78:52-60.

3. Haase NU, Weber L. Ascorbic acid losses during processing of French fries and potato chips. Journal of Food Engineering. 2003;56(2):207-209.

4. Alam MS, Amarjit S, Sawhney BK. Response surface optimization of osmotic dehydration process for aonla slices. J Food Sci Technol. 2010;47(1):47-54
5. Eitenmiller RR, Laden WO, Lin Ye. Ascorbic acid. In: Eitenmiller RR and Laden WO. Edn, Vitamin Analysis for the Health and Food Science. CRC Press, Boca Raton, FL, 1999;226-228.

6. Dublish RK, Chauhan GS, Bains GS. Nutritional quality of extruded rice, ragi and defatted soy flour blends. Journal of Food Science and Technology. 1988;25(2):35-39.

7. Kozlowska H, Elkowicz K, Rutkowski A. Thermal inactivation of trypsin inhibitors of soybean preparations added to meat. Meat Science. 1980;4:95-102.

8. Hutton CW, Campbell AM. Functional properties of soy concentrate and soy isolate in simple systems-NSI and water absorption. Journal of Food Science. 1997;42(4):454-457.

9. Mattil KF. The functional requirement of proteins in foods. Journal of American Oil and Chemical Society.1971;48:477-480.

10. Phillips RD, Chhinnan MS, Mendosa LG. Effect of temperature and moisture content on kinetics of TIA, protein in vitro digestibility and nitrogen solubility of cowpea flour. Journal of Food Science. 1983.48:1863.

11. Bhole SN. Studies on the development of cereal-pulses based convenience food. Unpublished Ph.D. thesis, PHTC, IIT, Kharagpur (W.B.), India. 1992.

12. Goyle A, Dugar N. Quality evaluation of three canteen snacks: nutritive, fat and bacteriological. Indian Food Packer, 1994;1:53-58.

13. Nath A, Chattopadhyay PK. Optimization of Oven Toasting for Improving Crispness and Other Quality Attributes of Ready to Eat Potato-Soy Snack Using Response Surface Methodology. Journal of Food Engineering. 2007;80(4):1282-1292.

14. Khetarpaul N, Grewal RB, Goyal R, et al. Development of partially defatted soy flour and dhal. Food Chemistry. 2014;87:355-359. 
15. Nath A, Chattopadhyay PK, Majumder GC. High temperature short time air puffed ready-to-eat (RTE) potato snacks: process parameter optimization. Journal of Food Engineerin. 2007;80:770-780.

16. Ranganna S. Handbook of Analysis and Quality Control for Fruits and Vegetable Products. $2^{\text {nd }}$ ed. Tata McGraw Hill Publishing Co. Ltd. New Delhi. 1995.

17. AOAC. Official methods of analysis of the Association of Official Analytical Chemists. 14 ${ }^{\text {th }}$ ed, Washington, DC. 1984.

18. Akeson WR, Stahmann MA. A pepsin-pancreatin digest index of protein quality. J Nutr. 1964;83(1):257-261.

19. BIS. Specification for edible full-fat and low fat-soya flour. Optimum requirements, IS: 7836-1975 and 7837-1975. Bureau of Indian Standards, New Delhi. 1975

20. Mudambi SR, Rajagopal MV. The nutrients. In: Fundamentals of Food and Nutrition. Wiley Eastern Ltd., New Delhi, 1983.

21. Kulkarni KD, Kerure YE, Kulkarni DN. Evaluation of potato cultivars for flour production. Beverage and Food World. 1988;8: 214-221.

22. Marwaha RS. Processing of potatoes: current status, need, future potential and suitability of Indian varieties - a critical appraisal. Journal of Food Science and Technology. 1997;34:457-471.
23. Tripathi AK, Misra AK. Soybean- a consummate functional food: A review. Journal of Food Science and Technology. 2005;42(2):111-119.

24. Murugkar DA, Jha K. Effect of sprouting on nutritional and functional characteristics of soybean. Journal of Food Science and Technology. 2009;46(3):240-243

25. Akubor PI, Ukwuru MU. Functional properties and biscuit making potential of soybean and cassava flour blends. Plant Food for Human Nutrition. 2003;55(1):1-12.

26. Chauhan GS, Verma NS, Bains GS. Effect of extrusion cooking on nutritional quality of extruded rice-legume blends. Paper presented in $5^{\text {th }}$ Indian Convention of Food Scientists and Technologists, 03-05 Apr, New Delhi, 1985.

27. Laul MS, Bhalerao SD, Mulmuley GV. Studies on the preparation of extruded finger shaped snack foods with protein enrichment. Indian Food Packer. 1985;32:68-77.

28. Kulkarni KD, Joshi KC. Potato starch soy-blends: Possible effects of starch properties on few aspects of end products. Indian Food Packer $1992 ; 66: 38-49$. 